\title{
Cytolysin potential of some of the di and triterpenoids from the seeds of Guilandina bonducella $L$.
}

\author{
Ayesha ASIFa, M. Asif SAEED \\ a Faculty of Pharmacy, University of Central Punjab, Lahore, 54000, Pakistan \\ bCollege of Pharmacy, University of the Punjab, Lahore, Pakistan. (Retired)
}

\begin{abstract}
Cytolysin potential of the constituents of Guilandina bonducella seeds was evaluated. For this purpose, di and triterpenes had been investigated. Two di and four triterpenes from the EtOAc extract of $G$. bonducella seeds were isolated, purified by chromatographic and re-crystallization methods and identified by comparative spectroscopic data. Cytolysin potential of these compounds was carried out on brine shrimp's (Artemia salina) larvae (nauplii), compared with positive controlled colchicine's reaction and evaluated by $\mathrm{LD}_{50^{\circ}}$.

Diterpenes (neocaesalpin $C$, neocaesalpin $D$ ) and triterpenes ( $\alpha$-amyrin, $\beta$-amyrin, lupeol and lupeol acetate) exhibited a marked cytolytic reaction, even though their intensities differ from each other and with the colchicine. EtOAc extract of $G$. bonducella seeds contained diterpenes (neocaesalpin-C and neocaesalpin-D) and triterpenes ( $\alpha$-amyrin, $\beta$-amyrin, lupeol and lupeol acetate). These compounds had cytotoxic ability to the brine shrimp's larvae.
\end{abstract}

Keywords: Cytolysin potential; ditepenoid and triterpenoid componds; Guilandina obonducella; $\mathrm{LD}_{50}$.

\section{INTRODUCTION}

Guilandina bonducella L. or Caesalpinia bonduc (L.) Roxb. or Caesalpinia bonducella (L.) Fleming or Caesalpinia crista auct. Amer., commonly called as 'fever nut' 'bonduc nut' or 'nicker nut' (Katkaranja) by the indigenous people. It

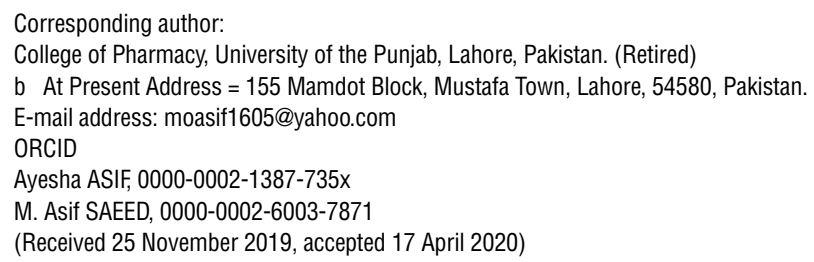


is an important medicinal plant, belongs to the family Caesalpiniaceae. It had been reported in phratry medicine and in ancient Ayurveda, Siddha, Unani and Homoeopathic Holy Scripturies ${ }^{1,2}$. This plant is a prickly shrub or a small tree, distributed in subtropical and temperate regions of Pakistan and abundantly established itself in the Punjab Province during the bedewed season ${ }^{3}$.

Leaves and roots of this plant had been extensively employed in canonical medicines for the treatment of enumerating diseases ${ }^{4-7}$. It had been investigated that various solvent extracts of leaves of this plant exhibited substantial antidiarrhoeal, cytotoxic and antibacterial activities ${ }^{4}$. Anti-inflammatory, antioxidant, antimicrobial, antifungal, antipyretic, analgesic, anti-asthmatic, anti-diabetic, anti-filarial, anti-tumor, adaptogenic, anti-convulsant, anti-spasmodic, nootropic, anti-feedant, anti-amoebic, anti-oestrogenic, anxiolytic, diuretic, hepato-protective and immuno-modulatory activities of the seeds of this herb had also been reported ${ }^{4-9}$. The consequences of methanolic extract of the whole herb on the lipid peroxidation (LPO), glutathione content (GSH), superoxide dismutase (SOD) and catalase (CAT) was carry out by Gupta et al. and concluded that a significant diminish in the intensity of the tumor and packed feasible cell counts were detected ${ }^{8,9}$ while its impression on hematology and hepato-renal functions in mice were ascertained by Kumar et al..$^{11,12}$.

As regards the presence of phtochemical ingredients were concerned, phtochemical compounds belonging to different classes such as alkaloids, glycosides, di- and triterpenoids, saponins, phytosterols, phenolic compounds, flavonoids and carbohydrates from various solvent extracts had been isolated from various species of the genus Guilandina ${ }^{2,3}$. Phytochemical screening of $G$. bonducella's leaves and seeds, revealed the presence of non-toxic ${ }^{13-17}$ and cytotoxic flavonoids ${ }^{18}$. Large number of diterpenenoid ${ }^{13-15}, 16,17,19-25,27-31$ and triterpenoid ${ }^{32,33}$ compounds chiefly from the ethanolic extracts of the seeds and other parts of this plant had previously been isolated and characterized by many research workers. Many fatty acids triglycerides, including palmatic, stearic, octadec-4-enoic and octadeca-2,4-dienoic acids from the seed kernels of this species had also been isolated and identified ${ }^{35}$.

No attempt had been made to isolate and evaluate the harmful effects of its constituents. Our phytochemical and biological investigation of local natural products have led to the isolation of terpenoid compounds from G. bonducella seeds. In the present communication, we delineate the cytolysin potential of some of the di and triterpenoids, isolated from the seeds of this species, on brine shrimp's (Artemia salina Leach) larvae (nauplii) followed by fractionation, to isolate and characterize its active compounds whose cytolysin potential was evaluated by computing their $\mathrm{LD}_{50^{\circ}}$. 


\section{METHODOLOGY}

\section{General Experimental Procedures}

Unless otherwise stated, the chemicals used were of analytical grades. Concentrations were carried out under reduced pressure at bath temperatures not exceeding $50^{\circ} \mathrm{C}$. Melting points were determinate on Perfit apparatus with the help of open capillary tubing and were unadmonished. UV spectra of the compounds were measured on Hitachi 270-30 spectrophotometer in $\mathrm{MeOH}$ while IR spectra were procured as $\mathrm{KBr}$ disc or as thin films on $\mathrm{NaCl}$ discs on Pye-Unicam SP-8400 spectrophotometer. ${ }^{1} \mathrm{HNMR}$ spectra were obtained in deuterated DMSO- $\mathrm{d}_{6}$ solvent on Bruker NMR at $270 \mathrm{MHz}$ using tetramethylsilane (TMS) as an internal standard. ${ }^{13} \mathrm{CNMR}$ spectra were carried out on Bruker AM-300 NMR, spectrometers with $75 \mathrm{MHz}$, at $27 \pm 1.5^{\circ} \mathrm{C}$ and with $0.2-0.5 \mathrm{mM} / \mathrm{ml}$ sample concentrations, using $10 \mathrm{~mm}$ tubes and deuterated DMSO- $\mathrm{d}_{6}$ as a solvent. Tetramethylsilane (TMS) was used as an internal reference. Chemical shifts were calculated for both ${ }^{1} \mathrm{HNMR}$ and ${ }^{13} \mathrm{CNMR}$ spectra in $\delta$ (ppm). EI and FD mass spectra were recorded on a Varian MAT-312 double focusing mass spectrometer using direct inlet method. FAB (positive) in glycerin, were conducted on JEOL JMS-110 spectrometer. Column chromatography was carried out on silica gel 60 (70-230 mesh ASTM No. 7734 of E. Merck, Damstadt, Germany), monitoring its fractions by analytical TLC. Both the analytical and preparatory TLC were performed with silica gel $\mathrm{PF}_{254+366}$ (from E. Merck, Damstadt Germany) on $10 \times 20$ or $20 \times 20 \mathrm{~cm}$ glass plates. Analytical TLC with a depth of $0.25 \mathrm{~mm}$ thicknesses and preparatory TLC with $0.75 \mathrm{~mm}$ thick was utilized, where the samples were applied as thin sports on analytical TLC and as narrow bands on preparatory TLC. Spots on chromatograms were visualized by a combination of UV fluorescence, exposing on 254/365 nm UV light, or with $\mathrm{I}_{2}$ vapors, or with anisaldehyde $/ \mathrm{H}_{2} \mathrm{SO}_{4}$ spraying reagent or with Liebermann-Burchard spraying reagent ${ }^{36}$. The separated bands on preparatory TLC were scraped off and eluted with methanol.

\section{Plant Materials}

Ripened seeds of Guilandina bonducella L. were accumulated from the uncultivated and wasted areas of Lahore region of Punjab (Central plain areas of Pakistan) in July / August 2018. These were authenticated by Prof. Dr. ZaheerUd-Khan, in-charge herbarium, Department of Botany, Government College University, Lahore, Pakistan. A voucher specimen of the sample (No. P-cog. 0156) was kept in Herbarium of Pharmacognosy Section, Faculty of Pharmacy, University of Central Punjab, Lahore for further reference. The seeds were air dried at laboratory temperature and stored in an amber glass bottle after pulverizing. 


\section{Extraction and Isolation}

8.o kg of seed powder was soaked in $\mathrm{MeOH}$ for three weeks. It was percolated and the filtrate was concentrated under reduced pressure then to dryness to generate dark-brown $130 \mathrm{~g}$ of a residue. The dried residue was partitioned between light petroleum ether $\left(40-60^{\circ} \mathrm{C}\right)$ and $\mathrm{H}_{2} \mathrm{O}$. The aqueous layer was further concentrated and segmented between EtOAc and $\mathrm{H}_{2} \mathrm{O}$. The EtOAc extract was condensed by removing the solvent under reduced pressure and $461 \mathrm{~g}$ (about $5.75 \%$ yield) of the material was obtained. $300 \mathrm{~g}$ of the EtOAc extract was incorporated with a minimum amount of silica gel using methanol and after drying, it was pulverized into a fine powder. It was then adsorbed over silica gel column and chromatographed in light petroleum ether $\left(40-60^{\circ} \mathrm{C}\right)$. The column was eluded with $100 \%$ light petroleum ether, petroleum ether- $\mathrm{CHCl}_{3}, \mathrm{CHCl}_{3}$ and $\mathrm{CHCl}_{3}-\mathrm{MeOH}$, while increasing the amount of latter solvent gradually. The fractions holding similar compounds were pooled after monitored by analytical TLC. The pooled fractions were evaporated to dryness under reduced pressure.

\section{Compound-1}

Compound-1 was eluded from the silica gel column with light petroleum ether/ $\mathrm{CHCl}_{3}$ (95:5) with the initial 50 fractions (50ml each) and by preparatory TLC after using petroleum ether $/ \mathrm{CHCl}_{3}$ (90:10). It was obtained as colorless prisms like crystals ( $85 \mathrm{mg}$, with $0.03 \%$ yield) and had mp. $262-264^{\circ} \mathrm{C}$ after re-crystallization with hot $\mathrm{MeOH}$. This compound gave a single spot on three-dimensional TLC when petroleum ether $/ \mathrm{CHCl}_{3}$ (70:30, 80:20 and 90:10) were used as solvent systems. $[\alpha] D^{28}-52^{\circ}(c=0.036)$. FABMS, m/z: 489.2116 (Calcd for $\mathrm{C}_{24} \mathrm{H}_{36} \mathrm{O}_{9}$. Na+: 489.2100). EIMS, m/z (rel. intens. \%): $448 \mathrm{M}^{+}-\mathrm{H}_{2} \mathrm{O}$ (1), $430 \mathrm{M}^{+}-2 \times \mathrm{H}_{2} \mathrm{O}$ (11), $406 \mathrm{M}^{+}-\mathrm{CH}_{3} \mathrm{COOH}(25), 388 \mathrm{M}^{+}-\mathrm{CH}_{3} \mathrm{COOH}-\mathrm{H}_{2} \mathrm{O}(17), 370 \mathrm{M}^{+}-\mathrm{CH}_{3} \mathrm{COOH}$ $-2 \times \mathrm{H}_{2} \mathrm{O}$ (53), $346 \mathrm{M}^{+}-2 \times \mathrm{CH}_{3} \mathrm{COOH}(44), 328 \mathrm{M}^{+}-2 \times \mathrm{CH}_{3} \mathrm{COOH}-\mathrm{H}_{2} \mathrm{O}$ (89), $310 \mathrm{M}^{+}-2 \times \mathrm{CH}_{3} \mathrm{COOH}-2 \mathrm{H}_{2} \mathrm{O}$ (100). IR (KBr) cm $\mathrm{cm}^{-1}: 3586$ (broad OH), 2948, 1734 (a strong ester group), 1364, 1257, 1229, 1036. UV $\lambda_{\max }(\mathrm{MeOH}) \mathrm{nm}(\log \varepsilon): 216$ (4.16). ${ }^{1} \mathrm{HNMR}, \delta: 5.68$ (H-1, d, $J=2.9$ ), 5.56 (H-2, ddd, $J=2.8,4.2,13.4$ ), 2.32 (H-3a, dd, $J=13.1,13.1$ ), 1.40 (H-3 $\beta$, dd, $J=4.2,13.4$ ), 2.43 (H-6a, dd, $J=5.8$,

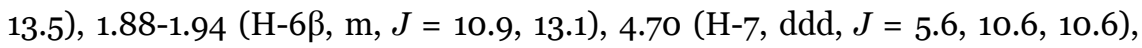
1.93-1.97 (H-8, m, $J=10.6,12.9$ ), 3.31 (H-9, ddd, $J=2.6,12.5,12.5$ ), a2.52(H-11, dd, $J=2.7,12.6$ ), $\beta 1.47$ (dd, $J=12.7,12.7$ ), 3.88 (H-14, dq, $J=4.6,7.3$ ), 5.82 (H-15, s), 1.58 (Me-17, d, $J=7.3$ ), 1.22 (Me-18, s), 1.14 (Me-19, s), 1.18 (Me-20, s), 1.98( $\left.\mathrm{CH}_{3} \mathrm{COO}, \mathrm{s}\right), 2.13\left(\mathrm{CH}_{3} \mathrm{COO}, \mathrm{s}\right) .{ }^{13} \mathrm{CNMR}, 8: 74.4(\mathrm{C}-1), 67.6(\mathrm{C}-2), 35.4$ (C-3), 40.5 (C-4), 78.6 (C-5), 36.5 (C-6), 66.2 (C-7), 47.9 (C-8), 32.6 (C-9), 45.5 (C-10), 38.6 (C-11), 106.4 (C-12), 171.3 (C-13), 33.6 (C-14), 113.6 (C-15), 175.2 (C16), 13.2 (C-17), 28.2 (C-18), 25.6 (C-19), 17.8 (C-20), 170.5, 170.8 ( $\left.\mathrm{CH}_{3} \mathrm{CO}\right), 20.6$, 
21.2 $\left(\mathrm{CH}_{3} \mathrm{CO}\right)$ (Fig. 1). The compound-1 was identified by comparing its spectral data with the reported data and with CAS ID = Cooo33244 as neocaesalpin $\mathrm{C}^{19}$.

\section{Compound-2}

Compound-2 was eluded from the column with light petroleum ether $/ \mathrm{CHCl}_{3}$ (85:15) with further 51 to 90 fractions (50ml each) and by preparatory TLC after using petroleum ether/ $\mathrm{CHCl}_{3}$ (85:15). 153mg (with $0.052 \%$ yield) of this compound was obtained as colorless needle like crystals with $\mathrm{mp} 213-215^{\circ} \mathrm{C}$ after recrystallization from hot EtOH. It appeared on TLC at hRf $=40$ (with petroleum ether $/ \mathrm{CHCl}_{3}$ 90:15) and gave a single spot on three-dimensional TLC when petroleum ether $/ \mathrm{CHCl}_{3}$ (70:30, 80:20 and 90:15) were used as solvent systems. [ $\alpha$ ] $\mathrm{D}^{25}+71.6^{\circ}(c=0.091)$. FABMS m/z: 433.2235 (Calcd for $\mathrm{C}_{24} \mathrm{H}_{32} \mathrm{O}_{7} \cdot \mathrm{H}+:$ 433.2227). EIMS, m/z (rel. intens. \%): $414\left(\mathrm{M}^{+}-\mathrm{H}_{2} \mathrm{O}\right.$ (7), $372 \mathrm{M}^{+}-\mathrm{CH}_{3} \mathrm{COOH}$ (10), $354 \mathrm{M}^{+}-$ $\mathrm{CH}_{3} \mathrm{COOH}-\mathrm{H}_{2} \mathrm{O}(42), 312 \mathrm{M}^{+}-2 \times \mathrm{CH}_{3} \mathrm{COOH}(59), 294 \mathrm{M}^{+}-2 \times \mathrm{CH}_{3} \mathrm{COOH}-\mathrm{H}_{2} \mathrm{O}$ (100). IR (KBr) cm ${ }^{-1}: 2946$ (broad OH), 1790, 1769, 1733, 1375, 1259, 1234. UV $\lambda_{\max }(\mathrm{MeOH}) \mathrm{nm}(\log \varepsilon): 281$ (4.26). ${ }^{1} \mathrm{HNMR}, 8: 5.70(\mathrm{H}-1, \mathrm{~d}, J=3.2), 5.62(\mathrm{H}-2$,

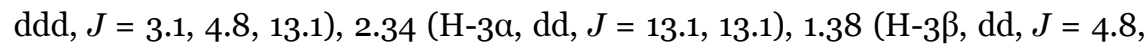

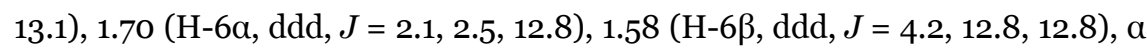
2.01-2.07m; $\beta 1.18 \mathrm{~m}(\mathrm{H}-7), 1.75$ (H-8, ddd, $J=4.2,10.3,10.3$ ), 3.42 (H-9, br d, $J=10.3$ ), 5.92 (H-11, br s), 2.68 ( $\mathrm{H}-14, \mathrm{dq}, J=4.3,7.3), 5.87$ (H-15, d, $J=0.8$ ), 0.92 (Me-17, d, $J=7.4$ ), 1.13 (Me-18, s), 1.04 (Me-19, s), 1.06 (Me-20, s), 2.03 $\left(\mathrm{CH}_{3} \mathrm{COO}, \mathrm{s}\right), 2.09$ ( $\left.\mathrm{CH}_{3} \mathrm{COO}, \mathrm{s}\right) .{ }^{13} \mathrm{CNMR}, 8: 73.4$ (C-1), 67.8 (C-2), $36.3(\mathrm{C}-3)$, 40.8 (C-4), 76.8 (C-5), 26.6 (C-6), 23.7 (C-7), 37.8 (C-8), 36.6 (C-9), 45.5 (C-10), 111.3 (C-11), 151.5 (C-12), 161.9 (C-13), 33.6 (C-14), 110.9 (C-15), 170.8 (C-16), 14.6 (C-17), 27.4 (C-18), 24.8 (C-19), 19.8 (C-20), 170.3 , 170.5 $^{\mathrm{b}}\left(\mathrm{CH}_{3} \mathrm{CO}\right), 20.6,20.8$ $\left(\mathrm{CH}_{3} \mathrm{CO}\right)$ (Fig. 1). The compound-2 was identified by comparing its spectra data with the reported data and with CAS ID $=$ Cooo33245 as neocaesalpin $\mathrm{D}^{19}$.

\section{Compound-3}

Compound-3 was eluded from the column with light petroleum ether $/ \mathrm{CHCl}_{3}$ (80:25) with further 91 to 135 fractions (50ml each) and by preparatory TLC after using petroleum ether $/ \mathrm{CHCl}_{3}$ (80:25). $73 \mathrm{mg}$ of this compound (0.025\% yield) was obtained as light yellow needles and with $\mathrm{mp} 183-184^{\circ} \mathrm{C}$ after re-crystallization from hot acetone. This compound indicated a single spot on threedimensional TLC when petroleum ether $/ \mathrm{CHCl}_{3}(60: 40,70: 30$ and 80:20) were used as solvent systems. EIMS, m/z (rel. intens. \%): $426\left[\mathrm{C}_{30} \mathrm{H}_{50} \mathrm{O}, \mathrm{M}^{+}\right]$(24), 411 $[\mathrm{M}-\mathrm{Me}]^{+}(18), 408\left[\mathrm{M}-\mathrm{H}_{2} \mathrm{O}\right]^{+}(24), 218\left[\mathrm{M}-\mathrm{C}_{14} \mathrm{H}_{24} \mathrm{O}\right]^{+}(100), 207\left[\mathrm{M}-\mathrm{C}_{16} \mathrm{H}_{27} \mathrm{O}\right]^{+}$

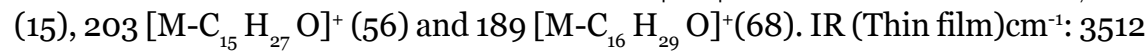
(broad $\mathrm{OH}), 3058,1638$ and 822 (trisubstituted double bond). ${ }^{1} \mathrm{HNMR}, \delta: 1.98$ (ddd, $J=8.1,9.6,4 . \mathrm{OH}_{\mathrm{z}}, \mathrm{H}-1$ ), 1.92 (m, H-2), 3.13 (dd, $J=5.5,8 . \mathrm{H}_{\mathrm{z}}, \mathrm{H}-3$ ), 1.27 
(m, H-5), 1.52 (m, H-6), 1.31 (m, H-7), 1.57 (dd, $J=2.1,9.1 \mathrm{H}_{\mathrm{z}}, \mathrm{H}-9$ ), 1.67 (dd, $J$ $\left.=9.1,3.5 \mathrm{H}_{\mathrm{z}}, \mathrm{H}-11\right), 5.24$ (m, H-12), 1.51 (dd, $\left.J=9.1,3.5 \mathrm{H}_{\mathrm{z}}, \mathrm{H}-15\right), 1.30$ (dd, $J=$ 16.1, 8.3 $\mathrm{H}_{\mathrm{z}}, \mathrm{H}-16$ ), 1.40 (m, H-19), 1.57 (dd, $\left.J=2.1,9.1 \mathrm{H}_{\mathrm{z}}, \mathrm{H}-21\right), 1.65$ (dd, $J=$ 9.1, 3.5 $\left.\mathrm{H}_{\mathrm{z}}, \mathrm{H}-22\right), 0.84$ (brs, H-23), 0.95 (brs, H-24), 0.90 (brs, H-25), 0.74 (brs, $\mathrm{H}-26), 1.06$ (brs, H-27), 0.78 (brs, H-28), 0.92 (3H, d, $\left.J=6.7 \mathrm{H}_{\mathrm{z}}, \mathrm{H}-29\right), 0.81$ (d, $J=6.9 \mathrm{~Hz}, \mathrm{H}-30) .{ }^{13} \mathrm{CNMR}, 8: 40.1$ (C-1), 27.5 (C-2), 78.1 (C-3), 37.5 (C-4), 55.6 (C-5), 20.7 (C-6), 32.7 (C-7), 40.6 (C-8), 48.1 (C-9), 37.5 (C-10), 23.6 (C-11), 124.3 (C-12), 138.7 (C-13), 41.5 (C-14), 28.8 (C-15), 27.7 (C-16), 34.1 (C-17), 59.8 (C-18), 40.1 (C-19), 39.2 (C-20), 31.2 (C-21), 42.8 (C-22), 28.6 (C-23), 16.1 (C-24), 16.2 (C-25), 17.5 (C-26), 24.1 (C-27), 28.8 (C-28), 17.5 (C-29),20.7 (C-30) (Fig. 1). The compound- 3 was recognized by comparing its spectra data with the reported data and with CAS ID = Cooo3737 as $\alpha$-Amyrin ${ }^{33}$.

\section{Compound-4}

Compound-4 was obtained from the column with light petroleum ether $/ \mathrm{CHCl}_{3}$ (80:30) with further 136 to 175 fractions (50ml each) and by preparatory TLC after using petroleum ether $/ \mathrm{CHCl}_{3} / \mathrm{MeOH}$ (75:25:3). $67 \mathrm{mg}$ of this compound (0.023\% yield) was obtained as light yellow needles after re-crystallization from hot $\mathrm{EtOH}$ and with $\mathrm{mp} .197-198^{\circ} \mathrm{C}$. This compound showed a single spot on three-dimensional TLC when petroleum ether $/ \mathrm{CHCl}_{3}(60: 45,70: 35$ and 80:25) were used as solvent systems. EIMS, m/z (rel. intens. \%): $426\left[\mathrm{C}_{30} \mathrm{H}_{50} \mathrm{O}, \mathrm{M}^{+}\right]$

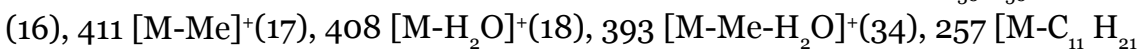
$\mathrm{O}^{+}(2 \mathrm{O}), 218\left[\mathrm{M}-\mathrm{C}_{14} \mathrm{H}_{24} \mathrm{O}\right]^{+}(100), 207\left[\mathrm{M}-\mathrm{C}_{16} \mathrm{H}_{27} \mathrm{O}\right]^{+}(11), 203\left[{\mathrm{M}-\mathrm{C}_{15}}_{2} \mathrm{H}_{27} \mathrm{O}\right]^{+}(46)$ and $189\left[\mathrm{M}^{-\mathrm{C}_{16}} \mathrm{H}_{29} \mathrm{O}\right]^{+}(58)$. IR, (Thin film) $\mathrm{cm}^{-1}: 3510$ (broad OH), 3055, 1636 and 820 (trisubstituted double bond). ${ }^{1} \mathrm{HNMR}, \delta: 1.31$ (ddd, $J=8.2,6.1,11.1 \mathrm{H}_{\mathrm{z}}$, $\mathrm{H}-1$ ), 1.60 (m, H-2), 1.37 (m, H-6), 1.40 (m, H-7), 1.87 (dd, $J=4.7,3.5 \mathrm{H}_{\mathrm{z}}, \mathrm{H}-11$ ), 1.60 (dd, $J=3.1,4 . \mathrm{oH}_{\mathrm{z}}, \mathrm{H}-15$ ), 1.53 (m, H-16), 2.77 (dd, $J=11.3,6.2 \mathrm{H}_{\mathrm{z}} \mathrm{H}-18$ ), 1.37 (m, H-19), 1.87 (dd, $\left.J=4.7,3.5 \mathrm{H}_{\mathrm{z}}, \mathrm{H}-21\right), 1.45$ (dd, 3.5, 4.0H, $\left.\mathrm{H}-22\right), 1.03(3 \mathrm{H}$ , s, Me-23), o.82 (6H, s, Me-24), 0.94 (3H, s, Me-25), 1.05 (3H, s, Me-26), 1.12 (3H, s, Me-27), o.8o (brs, Me-29) and 0.91 (3H, brs, Me-30). ${ }^{13} \mathrm{CNMR}, 8: 40.1$ (C-1), 27.7 (C-2), 78.3 (C-3), 37.5 (C-4), 55.4 (C-5), 20.7 (C-6), 32.7 (C-7), 39.2 (C-8), 48.1 (C-9), 37.5 (C-10), 23.6 (C-11), 122.6 (C-12), 145.5 (C-13), 41.5 (C-14), 27.6 (C-15), 27.7 (C-16), 34.1 (C-17), 48.1 (C-18), 48.0 (C-19), 31.2 (C-20), 34.0 (C-21), 37.5 (C-22), 28.6 (C-23), 16.1 (C-24), 16.0 (C-25), 17.5 (C-26), 27.5 (C-27), 28.6 (C-28), 32.7 (C-29), 23.6 (C-30) (Fig. 1). The compound-4 was identified by comparing its spectra with reported data and with CAS ID $=$ Cooo3738 as $\beta$-Amyrin ${ }^{33}$. 


\section{Compound-5}

Compound-5 was received from the column with light petroleum ether/ $\mathrm{CHCl}_{3}$ (60:40) from further 176 to 216 fractions (50ml each) and by preparatory TLC after using petroleum ether $/ \mathrm{CHCl}_{3} / \mathrm{MeOH}$ (70:30:5). $149 \mathrm{mg}$ of this compound (0.051\% yield) was obtained as white needles after re-crystallization from hot $\mathrm{Me}_{2} \mathrm{CO}-\mathrm{MeOH}$ (1:1 mixture) and with mp. $216-217^{\circ} \mathrm{C}$. This compound displayed a single spot on three-dimensional TLC when petroleum ether $/ \mathrm{CHCl}_{3}(60: 45$, 70:35, 80:25) were used as solvent systems. EIMS, m/z (rel. intens. \%): 426 $\left[\mathrm{C}_{30} \mathrm{H}_{50} \mathrm{O}, \mathrm{M}^{+}\right](21), 411[\mathrm{M}-\mathrm{Me}]^{+}(26), 408\left[\mathrm{M}-\mathrm{H}_{2} \mathrm{O}\right]^{+}(32), 393\left[\mathrm{M}-\mathrm{Me}-\mathrm{H}_{2} \mathrm{O}\right]^{+}(36)$, $385[\mathrm{M}-41]^{+}(14), 220\left[{\mathrm{M}-\mathrm{C}_{15}}^{\mathrm{H}} \mathrm{H}_{26}\right]^{+}(82), 218\left[\mathrm{M}-\mathrm{C}_{14} \mathrm{H}_{24} \mathrm{O}\right]^{+}(56), 207\left[{\mathrm{M}-\mathrm{C}_{16}}\right.$ $\left.\mathrm{H}_{27}\right]^{+}(24), 189\left[\mathrm{M}-\mathrm{C}_{16} \mathrm{H}_{29} \mathrm{O}\right]^{+}(100)$ and $139\left[\mathrm{M}-\mathrm{C}_{21} \mathrm{H}_{35}\right]^{+}(71)$. IR, (Thin film) $\mathrm{cm}^{-1}$ : 3452 (broad $\mathrm{OH}$ ), 3076, 1645 and 883 (exomethylene group). ${ }^{1} \mathrm{HNMR}, 8: 4.78$ and $4.65(2 \mathrm{H}$, brs, $1 \mathrm{H}$ each, $\mathrm{H}-29), 3.22\left(1 \mathrm{H}, \mathrm{dd}, J=9.6 \mathrm{H}_{z}, J=4.7 \mathrm{H}_{z}, \mathrm{H}-3\right), 1.64$ ( $3 \mathrm{H}, \mathrm{brs}, \mathrm{Me}-30), 1.07$ (3H, s, Me-26), 0.96 (3H, s, Me-23), 0.98 (3H, s, Me-27), 0.84 ( $3 \mathrm{H}, \mathrm{s}, \mathrm{Me}-25), 0.81$ (3H, s, Me-28) and 0.80 (3H, s, Me-24). ${ }^{13} \mathrm{CNMR}, \delta$ : 38.63 (C-1) 27.53(C-2), 78.82(C-3), 38.75 (C-4), 55.30(C-5), 18.32(C-6), 34.28 C-7), 40.84(C-8), 50.46C-9), 37.12 (C-10), 20.98(C-11), 25.27(C-12), 38.18 (C-13), 42.86 (C-14), 27.41(C-15), 35.52 (C-16), 92.94(C-17), 48.24(C-18), 47.79 (C-19), 150.66 (C-20), 92. 91(C-21), 39.88(C-22), 28.06(C-23), 15.49(C-24), 16.16(C-25), 15.92(C-26), 14.54 (C-27), 18.15 (C-28), 109.28 (C-29) and 19.26(C-30) (Fig.1). The compound- 5 was recognized by comparing its spectral data with the reported data and with CAS ID = Cooo29492 as being Lupeol ${ }^{11}{ }^{32} 34$.

\section{Compound-6}

Compound-6 was prevailed from the column with light petroleum ether/ $\mathrm{CHCl}_{3}$ (50:50) with further 217 to 257 fractions (50ml each) and by preparatory TLC after using petroleum ether $/ \mathrm{CHCl}_{3} / \mathrm{MeOH}(60: 40: 7) .67 \mathrm{mg}$ of this compound (0.022\% yield) was obtained as white molded acicular crystals after re-crystallization from hot $\mathrm{MeOH}$ and with mp. $213-214^{\circ} \mathrm{C}$.This compound demonstrated a single spot on three-dimensional TLC when petroleum ether/ $\mathrm{CHCl}_{3}$ (50:50, 70:30 and 80:20) were used as solvent systems. EIMS, m/z (rel. intens. \%): 468

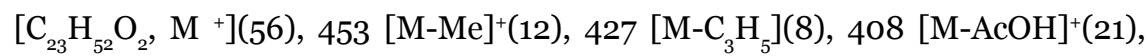

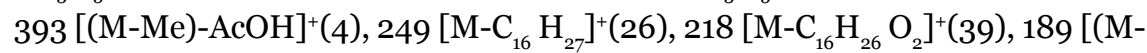

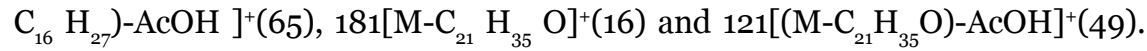
IR (Thin film) $\mathrm{cm}^{-1}: 3077$ (broad OH), 1712 (ester carbonyl), 1648 and 884 (exomethylene group). ${ }^{1} \mathrm{HNMR}, 8: 4.74$ and $4.64(2 \mathrm{H}, \mathrm{brs}, 1 \mathrm{H}$ each, $\mathrm{H}-29), 4.24(1 \mathrm{H}$, dd, $\left.J=9.8 \mathrm{H}_{z}, J=4.5 \mathrm{H}_{z}, \mathrm{H}-3\right), 2.13\left(3 \mathrm{H}, \mathrm{s}, \mathrm{CH}_{3} \mathrm{COO}\right), 1.68\left(3 \mathrm{H}, \mathrm{dd}, J=1.28 \mathrm{H}_{z}\right.$, Me-30), 1.08 (3H , s, Me-26), 0.96 (3H, s, Me-23), 0.96 (3H, s, Me-27), 0.89 $(3 \mathrm{H}, \mathrm{s}, \mathrm{Me}-25), 0.77$ (3H, s, Me-28) and $0.78(3 \mathrm{H}, \mathrm{s}, \mathrm{Me}-24) .{ }^{13} \mathrm{CNMR}, 8: 38.46$ 
(C-1), 23.78 (C-2), 81.08 (C-3), 37.84 (C-4), 55.44 (C-5), 18.25 (C-6), 34.36 (C-7), 40.98 (C-8), 50.49 (C-9), 37.13 (C-10), 21.08 (C-11), 25.17 (C-12), 38.16 (C-13), 42.98 (C-14), 27.54 (C-15), 35.68 (C-16), 43.12 (C-17), 48.09 (C-18), 48.35 (C-19), 152.14 (C-20), 30.15 (C-21), 40.06 (C-22), 28.08 (C-23), 16.59 (C-24), 16.27 (C25), 16.07 (C-26), 14.54 (C-27), 18.08 (C-28), 19.37 (C-29), 109.53 (C-30), 21.35 $\left(\mathrm{CH}_{3} \mathrm{COO}\right)$ and $170.88\left(\mathrm{CH}_{3} \mathrm{COO}\right)$, (Fig. 1). The compound-6 was identified by comparing its spectral data with the reported data and with CAS ID $=$ Cooo3750 as being Lupeol acetate ${ }^{33,34}$.

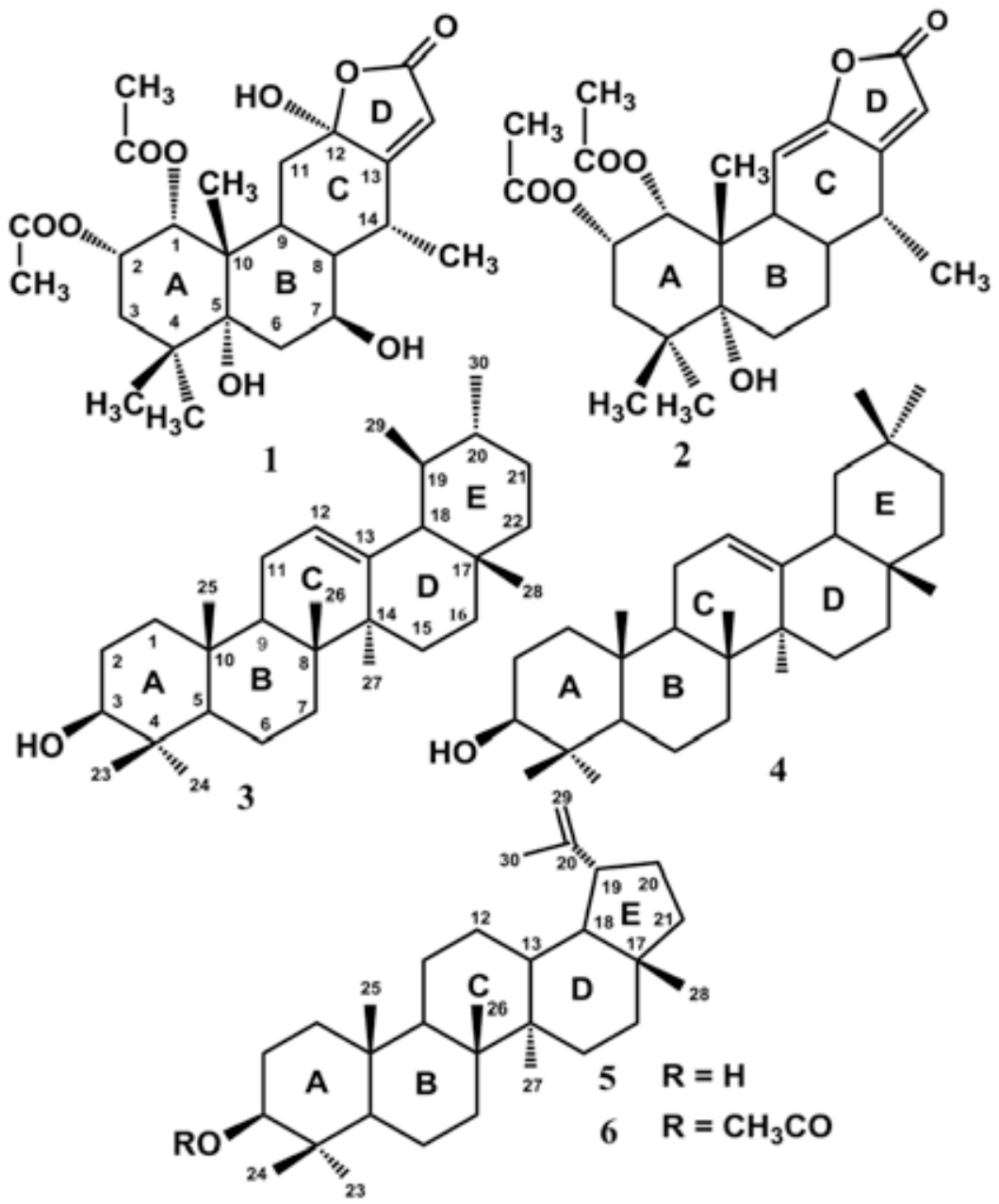

Figure 1: Diterpenoids and triterpenoids isolated from the seeds of $G$. bonducella. 


\section{Brine Shrimp (Artemia salina Leach) Lethality Bioassay}

This assay was adapted from the literature ${ }^{42-46}$. Eggs of brine shrimps (Artemia salina Leach) were purchased from a local fish store. A brine shrimp container was filled with artificial sea water (about 3.8\%) ${ }^{44-46}$. The seawater was incorporated with three different salts like $\mathrm{MgCl}_{2} \cdot 6 \mathrm{H}_{2} \mathrm{O}, \mathrm{Na}_{2} \mathrm{SO}_{4}$ and $\mathrm{CaCl}_{2} \cdot 2 \mathrm{H}_{2} \mathrm{O}^{44}$. Sea salt and yeast suspension (3mg dried yeast for each $5 \mathrm{ml}$ seawater sample) was also bought from the local fish store. Syringes of $5 \mathrm{ml}, 1 \mathrm{ml}, 500 \mu \mathrm{l}, 300 \mu \mathrm{l}, 200 \mu \mathrm{l}$, $100 \mu \mathrm{l}, 50 \mu \mathrm{l}$ and $10 \mu \mathrm{l}$ capacity and 2 dram vials (9 per sample and 3 for control) were also redeemed from the indigenous market. Sea salt solution was prepared artificially by dissolving $38 \mathrm{~g}$ sea salt in $1000 \mathrm{ml}$ distilled water. The final solution was filtered. The filtrate was taken in a small plastic tub that was divided by a partition, having holes in it. The brine shrimp's eggs were sprinkled in one portion of the tub and covered with a black carbon paper. Other half of the tub was illuminated with an electric lamp to attract the hatched brine shrimp's larvae. The solution in the tub was constantly supplied with regular air flow with at a normal pressure and suitable light conditions which were essential for the hatching process ${ }^{42-46}$. After 48 hours, the shrimp's eggs were hatched and matured as nauplii. The mature nauplii were then used further in the experiment. 20mg of each of the compound was taken in a small vial and dissolved in $2 \mathrm{ml}$ of methanol to serve as stock solution. From the stock solution, $500 \mu l$ 's, $400 \mu l, 300 \mu l, 200 \mu l$, $100 \mu \mathrm{l}, 80 \mu \mathrm{l}, 60 \mu \mathrm{l}, 40 \mu \mathrm{l}, 20 \mu \mathrm{l}, 10 \mu \mathrm{l}, 5 \mu \mathrm{l} 2.5 \mu \mathrm{l}$ and $1.25 \mu \mathrm{l}$ (corresponding to the 1000, 800, 600, 400, 200, 160, 120, 80, 40, 20, 10, 5 and 2.5 $\mu$ g respectively) were transferred to the vials with three replicates of each concentration of the isolated compound. The vials were placed in an open area for 24 hours for complete evaporation of methanol. $2 \mathrm{ml}$ of sea salt solution was then added to each vial. 10 brine shrimp's larvae were reassigned to each vial (30 brine shrimp's larvae per dilution) with the help of a long-tipped dropper. Total volume of liquid in each vial was adjusted to $5 \mathrm{ml}$ with sea salt solution. Sluggish or anechoic brine shrimp's larvae were counted for all concentrations of isolated compounds after 24 hours. Colchicine ${ }^{44-46}$ in the same concentrations was utilized as positive control. Total number of annihilated brine shrimps per dilution of each compound was tabulated. $\mathrm{LC}_{50}$ (lethal concentration in 50\% individuals) along with the upper and lower confidence limits of each compounds were calculated by probit analysis ${ }^{47}$, using a computer program ${ }^{48}$. The number of obliterated brine shrimp's larvae due to the results of the effects acquired by the six isolated compounds from the ethyl acetate extract of the pulverized seeds of $G$. bonducella and also by

colchicine, their $\mathrm{LC}_{50}$, along with the upper and lower confidence limits had been outlined in Table-1. 


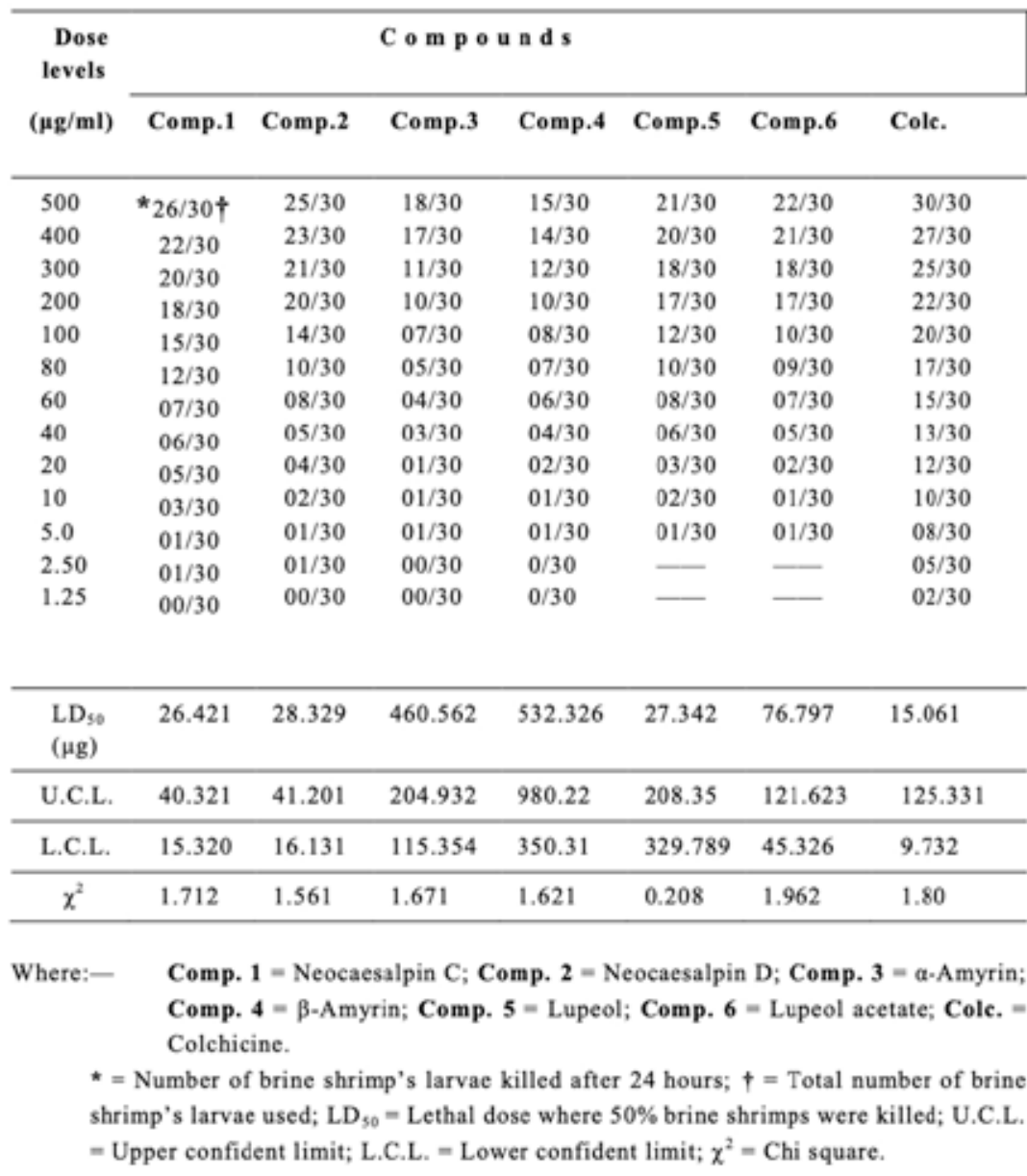

Table 1: Cytolysin potentials of the compounds isolated from the seeds of $G$. bonducella $\mathrm{L}$. herb on brine shrimps.

\section{RESULTS AND DISCUSSION}

It was a common observation that the disturbing feeling of Guilandina bonducella L. seeds during harvesting season of the crop, was demonstrated in most of the local farmers who deals with the removal of seeds from the plant. Skins of fingers, specifically the internal skin of index and first finger of their right hands were frequently involved. It often developed inflammatory eruption, after prolong handling seeds of the plants. Such skin eruption appeared to be due to some of the stringy actions induced by some of the materials from the seeds of the plant. This reaction was settled down after five or six days. This type of lubricious 
response of the seeds of this species on human skin motivated us to probe into the chemical nature of its hostile active compounds.

During the preliminary cytolysin attempt, it was ascertained that the $\mathrm{MeOH}$ extract of $G$. bonducella seeds was not fatal to the of brine shrimp's (Artemia salina) larvae (nauplii) than the EtOAc and $\mathrm{H}_{2} \mathrm{O}$ extracts. Moreover, EtOAc extract of the seeds appeared to be more assertive towards the brine shrimp's larvae, as compared to the $\mathrm{H}_{2} \mathrm{O}$ extract. EtOAc extracts was thus further fractionated through silica gel column, analytical thin-layered and preparatory thin-layered chromatography to isolate its active cytolysin ingredient/s. Six active cytolysin compounds, along with a number of non-active components were isolated from this extract and purified by chromatographic and re-crystallization methods. First two active compounds were identified as diterpenoid while other four were recognized as being triterpenoids by comparative physical and spectroscopic data (Fig. 1). Their spectroscopic data were based on EIMS, FAB-MS, ${ }^{1} \mathrm{HNMR}$ and ${ }^{13} \mathrm{CNMR}$ assignments. The structures of both the diterpenoid, compound-1 and compound-2 (i.e., neocaesalpin-C; neocaesalpin-D) were established by comparing their physical and spectroscopic data with previously reported similar compounds ${ }^{19}$ (Fig. 1) while the structures of the four triterpenoid compounds, compound- 3 to compound-6 (i.e., $\alpha$-amyrin ${ }^{33}, \beta$-amyrin ${ }^{33}$, lupeol ${ }^{32,34}$ and lupeol acetate ${ }^{34}$ ) were established after comparison with previously described compounds (Fig. 1).

Formerly many research workers had made good use of brine shrimp's larvae (i.e., nauplii of Artemia salina) assay for assessing the cytotoxicity and cytolysin potential of solvent extracts, fractions and phytochemical compounds from different natural crude drugs ${ }^{42-46}$. It appeared that the brine shrimp lethality bioassay was a simple measure for cytolytic potential of the natural products and their isolated compounds ${ }^{42-46}$. It was thus utilized to assist the bio-active maneuvering fractions which on conclusion lead to the bioactive cytolysin phytochemical compounds from our natural products. It was estimated that the difference between toxicity and efficacy of a drug was its dose. This assay often indicated that the fractionation of solvent extracts of natural products guided towards most-valuable bioactive toxic phytochemical compounds. Cytolysin activities were frequently expressed by the research workers in ppm or in $\mu \mathrm{g}$ as $\mathrm{LC}_{50}$ (Lethal dose where $50 \%$ of individuals in a population were killed) values with $95 \%$ confidence intervals ${ }^{42-46}$.

To compare the cytolysin potential of these compounds, the brine shrimp assay was engaged in measuring the $\mathrm{LD}_{50}$ at the time, at which the death of the brine shrimp's larvae was ascertained. The input data for a computer program consisted of the dose of testing materials (i.e., $\mathrm{MeOH}$ solution, EtOAc extract, column fractions or isolated compounds), the total number of test animal's larvae used 
and the number of test larvae responding (i.e., the number of dead larvae) to that dose. The program transformed the dose to the $\log$ dose and the test animal's larvae reacted to the probit of percentage responses. It then make fit a probit regression line to the resulting points and computed the values for $\mathrm{LD}_{50}$ along with their upper and lower confident limits ${ }^{47}$. The output data consisted of a listing of $\mathrm{LD}_{50}$, upper and lower confident limits and a value of $\chi^{2}$. The purpose of the $\chi^{2}$ test was to detect whether the assay, after transformation, was satisfactorily represented by a probit regression line. If the $\chi^{2}$ test pointed out a divergence of transformed results from linear shape, these could not be assigned to a random biological variation (i.e. if $\chi^{2}$ value is not significant at $p>0.05$, then the results obtained by probit analysis would not be legitimate) ${ }^{47}$.

The results indicated that both the EtOAc and $\mathrm{H}_{2} \mathrm{O}$ extracts of $G$. bonducella seeds had cytolysin potential against the brine shrimp's larvae but the EtOAc extract was even more violent cytolysin than $\mathrm{H}_{2} \mathrm{O}$ extract, when compared with the known cytolysin compound, colchicine ${ }^{4-46}$. Colchicine was employed as positive controlled cytolysin material in this bioassay ${ }^{4-46}$. All the six terpenoid compounds (compound-1 to compound-6) (Fig.1) from this extract revealed a cytolysin potential against brine shrimp's (Artemia salina) larvae (nauplii) when compared with colchicine applied in the same concentrations ${ }^{45}$ (Table 1). The results also demonstrated that among all the six isolated compounds, the compound-1 (neocaesalpin C) and compound-2 (neocaesalpin D) were the most active cytolysin compounds (with $\mathrm{LD}_{50}=26.421$ and 28.329 ). Their $\mathrm{LD}_{50}$ values were nearly close to the colchicine $\left(\mathrm{LD}_{50}=15.061\right)$. Moreover, the compound-1 (neocaesalpin $\mathrm{C}$ ) appeared to be more active than compound-2 (neocaesalpin D) and exhibited the highest cytolysin activity (Table-1). Other four compounds i.e., compound-3 ( $\alpha$-amyrin); compound-4 ( $\beta$-amyrin); compound-5 (lupeol), compound-6 (lupeol acetate) (with $\mathrm{LD}_{50}=460.562,532.326,27.342$ and 76.797 respectively) displayed a lesser cytolysin activity than colchicine (Table-1). The results also indicated that the two compounds i.e., compound-3 ( $\alpha$-amyrin) and compound-4 ( $\beta$-amyrin) demonstrated the least cytolysin potential (with $\mathrm{LD}_{50}=460.562$ and 532.326) against the brine shrimp's larvae than colchicine (Table-1).

The potent cytolytic / toxic effect on brine shrimp's larvae, induced by neocaesalpin C, neocaesalpin D, lupeol and lupeol acetate from G. bonducella seeds was probably due to a rapid penetration through the larvae's skin and quickly bioavailable to the living tissues of the animals. These compounds perhaps caused a blockage of respiratory centers which ultimately stimulated a quick tissue deterioration in the larvae leading to their death. The comparatively less toxic reaction of $\alpha$-amyrin and $\beta$-amyrin was possibly due to their direct actions, at some of the receptor sites in the animal's larvae. 
It was concluded that the EtOAc extract of $G$. bonducella seeds contained related cytolysin di and triterpenes which could be hostile not only to the brine shrimp's larvae but might also be insalubrious to the bodies of higher animals and human beings. Further work was necessitated to amplify this property through the preparation of derivatives of these active molecules, which would perhaps be elaborated for the structure-activity relationship of such important cytolysin molecules, both for in vivo and in vitro studies. These cytolysin molecules and their derivatives might also be important against animal's and human's cancerous tissues, which could further be tested with the standard processes of $\mathrm{WHO}^{49}$. Further work had also been designed to ascertain some cytolysin inhibitor/s from our natural sources, which could overcome the adverse action of such phytochemical compound/s from $G$. bonducella seeds and related species of the family Caesalpiniaceae.

\section{ACKNOWLEDGMENTS}

The author and co-author are thankful to the staff of the Department of Botany, Government College University (GCU) Lahore and also Prof. Dr. Zaheerud-Khan, in-charge herbarium for authenticating the materials. Thanks, are also presented to the staff of Applied Chemistry Section, PCSIR Laboratories, Lahore, Pakistan for obtaining EIMS, FABMS, ${ }^{1} \mathrm{H}$ NMR, and ${ }^{13} \mathrm{C}$ NMR spectra. Other thanks are acquiesce to the staff of Department of Pharmacognosy, Faculty of Pharmacy, Karachi University Karachi Pakistan for obtaining the eggs of brine shrimp (Artemia salina Leach). 


\section{REFERENCES}

1. Manikandaselvi, S.; Vadivel, V.; Brindha, P. Caesalpinia bonducella L. A nutraceutical plant. J. Chem. Pharmac. Res. 2015, 7(12), 137-142.

2. Moon, K.; Khadabadi, S. S.; Deokate, U. A.; Deore, S. L. Caesalpinia bonducella F-An overview. Rep. Opi. 2010, 2(3), 83-90.

3. Kashyap, S. V.; Joshi, A. C. Lahore District Flora, University of the Punjab, Lahore. 1936, p. 96.

4. Billah, M. M.; Islam, R.; Khatun, H.; Parvin, S.; Islam, E.; Islam, A. S. M.; Mia, A. A. Antibacterial, antidiarrhoeal, and cytotoxic activities of methanol extract and its fractions of Caesalpinia bonducella (L.) Roxb leaves. BMC Complem. Altern. Med. 2013, 13, 101.

5. Subbiah V, Nagaraja P, Narayan P, Nagendra HG. Evaluation of pharmacological properties of Caesalpinia bonducella seed and shell extract. Pharmacog. J. 2019, 11(1), 150-154.

6. Nazeerullah, K.; Sunil, K.; Pal, S. R.; Neelam, D. A. Pharmacognostic and pharmacological overview on Caesalpinia bonducella. Res. J. Pharm. Biochem. Sci. 2012, 3, 480-496.

7. Khedkar, A.; Mandavkar, Y. D.; Shinde, G.; Khalure, P.; Pravin, D. Diuretic effect of Caesalpinia bonduc in rats. Banglad. J. Pharmacol. 2011, 6, 61-63.

8. Gupta, M.; Mazumder, U. K.; Kumar, R. S.; Kumar, T. S. Studies on anti-inflammatory, analgesic and antipyretic properties of methanol extract of Caesalpinia bonducella leaves in experimental animal models. Iran. J. Phamacol. Therap. 2003, 2, 30-34.

9. Gupta, M.; Mazumder, U. K.; Kumar, R. S.; Sivakumar, T.; Vamsi, M. L. M. Anti-tumor activity and antioxidant status of Caesalpinia bonducella against ehrlich ascites carcinoma in Swiss albino mice. J. Pharmacol. Sci. 2004a, 94, 177-184.

10. Shukla, S.; Mehta, A.; John, J.; Singh, S.; Mehta, P.; Vyas, S. P. Antioxidant activity and total phenolic content of ethanolic extract of Caesalpinia bonducella seeds. Food Chem. Toxicol. 2009; $47,1848-1851$.

11. Kumar, R. S.; Kumar, K. A.; Murthy, N. V. Hepatoprotective and antioxidant effects of Caesalpinia bonducella on carbon tetrachloride induced liver injury in rats. Intern. Res. J. Pl. Sci. 2010, 1(3), 62-68.

12. Kumar, R. S.; Gupta, M.; Mazumdar, U. K.; Rajeshwar, Y.; Kumar, T. S, Gomathi, P.; Roy R. Effects of methanol extract of Caesalpinia bonducella and Bauhinia racemosa on the hematology and hepatorenal function in mice. J. Toxicol. Sci. 2005, 3O(4), 265-274.

13. Khandagale, P. D.; Puri, A. V.; Ansari. Y. N.; Patil, R. Y. Pharmacognostic, physiochemical and phytochemical investigation of Caesalpinia bonducella (L.) Roxb. seed. Intern. J. Pharm. Bio. Sci. 2018, 8(3), 461-468.

14. Sembiring, E. N.; Elya, B.; Sauriasari, R. Phytochemical screening, total flavonoid and total phenolic content and antioxidant activity of different parts of Caesalpinia bonduc (L.) Roxb. Pharmacog J. 2018, $10(1)$, 123-127.

15. Ogunlana, O. O.; Ogunlana, O. E.; Ntube, C. A.; Olagunju, J. A.; Akindahunsi, A. A. Phytochemical screening and in vivo antioxidant activity of ethanolic extract of Caesalpinia bonduc (L.) Roxb. Gl. Res. J. Pharma. Sci. 2012, 1(1), 1-5.

16. Pramod, K. R,; Vibha, S. Comparison of the phytochemical analysis and phytochemical screening of leave and seeds of kat-karanj (Caesalpinia bonduc). Intern. J. Bio. Pharmac. Res. 2014, 5(4), 313-322.

17. Shelar, P. A.; Mandavkar, Y. D.; Khedkar, A. S.; Thorat, M. B.; Raje, V. N. Review on pharma- 
cology and phytochemistry of Caesalpinia bonduc. J. Curr. Pharma. Res. 2014, 4(4), 1309-1317. 18. Ogunlana, O. O.; He, W. J.; Fan, J. T.; Zeng, G. Z.; Ji, C. J.; Zheng, Y. Q.; Olagunju, J. A.; Akindahunsi, A. A.; Tan, N. H. Cytotoxic flavonoids from the young twigs and leaves of Caesalpinia bonduc (L.) Roxb. Pak. J. Pharma. Sci. 2015, 28(6), 2191-2198.

19. Kinoshita, T. Chemical studies on the Philippine crude drug Calumbibit (Seeds of Caesalpinia bonduc): The isolation of new cassane diterpenes fused with $\alpha, \beta$-Butenolide. Chem. Pharma. Bull. 2000, 48(9), 1375-1377.

20. Dickson, R. A.; Fleischer, T. C.; Houghton, P. J. Cassane-type diterpenoids from the genus Caesalpinia. Pharmacog. Comm. 2011, 1(1), 63-77.

21. Agbo, E. O.; Bashir, S.; Igoli, N. P.; Nnamonu, L. A.; Igoli, J. O.; Gray, A. I. Caesaldekarin, M. A new diterpene from Caesalpinia bonduc. J. Nat. Prod. Res. Upd. 2015, 1, 1-6.

22. Ata, A.; Gale, E. M.; Samarasekera, R. Bioactive chemical constituents of Caesalpinia bonduc (Fabaceae). Phytochem. Lett. 2009, 2(3), 106-109.

23. Kinoshita, T.; Kaneko, M,; Noguchi, H.; Kitagawa, I. New cassane diterpenes from Caesalpinia bonduc (Fabaceae). Heterocy. 1996, 43(2), 409-414.

24. Lyder, D. L.; Peter, S. R.; Tinto, W. F.; Bissada, S. M.; McLean, S.; Reynolds, W. F. Minor cassane diterpenoids of Caesalpinia bonduc. J. Nat. Prod. 1998, 61(12), 1462-1465.

25. Pascoe, K. O.; Burke, B. A.; Chan, W. R.; Caesalpin, F. A new furanoditerpene from Caesalpinia bonducella. J. Nat. Prod. 1986, 49(5), 913-915.

26. Budzikiewicz, H.; Wilson, J. M.; Djerassi, C. Mass spectrometry in structural and stereochemical problems XXXII. J. Amer. Chem. Soc. 1963, 85, 3688-3699.

27. Balmain, A.; Connolly, J. D.; Ferrari, M.; Ghisalberti, E. L.; Pagnoni, U. M.; Pelizzoni, F. The stereochemistry of the furanoditerpenoids $\alpha-, \beta-$, and $\delta$-caesalpin. Chem. Commu. 1971, 24, 1585-1692.

28. Balmain, A.; Bj'smer, K.; Connolly, J. D.; Ferguson, G. The constitution and stereochemistry of $\varepsilon$-caesalpin. Tetrahed. Lett. 1967, 8(49), 5027-5031.

29. Ahmad, V. U.; Ali, M. S.; Usmanghani, K. Bondenolide, a new diterpenoid from the seeds of Caesalpinia bonduc. Chem. Soc. 1997, 52(3), 410-412.

30. Peter, S. R.; Tinto, W. F.; McLean, S.; Reynolds, W. F.; Tay, L. L. Caesalpinin, a rearranged cassane furanoditerpene of Caesalpinia bonducella. Tetrahed. Lett. 1997. 38(33), 5767-5770.

31. Peter, S. R.; Tinto, W. F.; McLean, S.; Reynolds, W. F.; Yu, M. Bonducellpins A-D, new cassane furanoditerpenes of Caesalpinia bonduc. J. Nat. Prod. 1997, 6o(12), 1219-1221.

32. Adhyapak, S.; Dighe, V. A normal phase high performance thin layer chromatographic determination of two triterpenoids lupeol and beta-amyrin from Caesalpinia bonducella L. and Coccinia indica Wight \& Arn. Intern. J. Pharm. Pharmac. Sci. 2014, 6(1), 449-453.

33. Francisco, A. O.; Mariana, H. C.; Fernanda, R. C.; Roberto, C. P.; Regilane, M. S. Protective effect of $\alpha$ - and $\beta$-amyrin, a triterpene mixture from Protium heptaphyllum (Aubl.) March trunk wood resins, against acetaminophen-induced liver injury in mice. $J$. Ethnopharmacol. 2005, 98, 103-108.

34. Surendra, K.; Corey, E. J. A short enantioselective total synthesis of the fundamental pentacyclic triterpene lupeol. J. Amer. Chem. Soc. 2009, 131(39), 13928-13929.

35. Rastogi, S.; Shaw, A. K.; Kulshreshtha, D. K. Characterisation of fatty acids of antifilarial triglyceride fraction from Caesalpinia bonduc. Fitoterapia 1996, 67(1), 63-64. 
36. Wagner, H.; Bladt, S.; Zgainski, E. M. Plant Drug Analysis. Springer-Verlag, Berlin, Heidelberg, New York. 1984, pp. 299-304.

37. Zou, J. H.; Jungui, D.; Chen, X.; Yuan, J. Q. Pentacyclic triterpenoids from leaves of Excoecaria agallocha. Chem. Pharmac. Bull. 2006, 54(6), 920-921.

38. Nakanishi, T.; Imatomi, Y.; Murata, H.; Shigeta, K.; Iida, N.; Inada, A.; Murata, J.; Farrera, M. A. P.; Iinuma, M.; Tanaka, T.; Tajima, S.; Oku, N. A new and known cytotoxic aryl tetralintype lignans from stems of Bursera graveolens. Chem. Pharmac. Bull. 2005, 53(2), 229-231.

39. Xiao, W. L.; Li, R. T.; Huang, S. X.; Pu, J. X.; Sun, H. D. Review. Triterpenoids from the Schisandraceae family. Nat. Prod. Rep. 2008, 25, 871-891.

40. Wood, C. A.; Lee, K.; Vaisberg, A. J.; Kingston, D. G. I.; Neto, C. C.; Hammond, G. B. A bioactive spirolactone iridoid and triterpenoids from Himatanthus sucuuba. Chem. Pharmac. Bull. 2001, 49(11), 1477-1478.

41. Dat, N. T.; Cai, X. F.; Shen, Q.; Lee, I. S.; Kim, Y. H. New inhibitor against nuclear factor of activated T cells transcription from Ribes fasciculatum var. chinense. Chem. Pharmc. Bull. 2005, 53(1), 114-117.

42. Hamidi, M. R.; Jovanova, B.; Panovska, T. K. Toxicological evaluation of the plant products using brine shrimp (Artemia salina L.) model. Macedonian Pharmac. Bull. 2014, 6o(1), 9-18.

43. Naidu, J. R.; Ismail, R.; Sasidharan, S. Acute oral toxicity and brine shrimp lethality of methanol extract of Mentha spicata L. (Lamiaceae). Trop. J. Pharmac. Res. 2014, 13(1), 101-107.

44. Wu, C. An important player in brine shrimp lethality bioassay: The solvent. J. Adv. Pharm. Technol. Res. 2014, 5(1), 57, 58.

45. Ullah, M. O.; Haque, M.; Urmi, K. F.; Zulfiker, A. H.; Md-Anita, E. S.; Begum, M.; Hamid, K. Anti-bacterial activity and brine shrimp lethality bioassay of methanolic extracts of fourteen different edible vegetables from Bangladesh. Asi. Pace. J. Trop. Biomed. 2013, 3(1), 1-7.

46. Parra, L.A.; Yhebra, R. S.; Sardiñas, I. G.; Buela, L.I. Comparative study of the assay of Artemia salina $\mathrm{L}$. and the estimate of the medium lethal dose $\left(\mathrm{LD}_{50}\right.$ value $)$ in mice, to determine oral acute toxicity of plant extracts. Phytomed. 2001, 8, 395-400.

47. Finney, D. J. Probit Analysis, Cambridge University Press, London, 3rd ed. 1971.

48. BioStat. Ver. 6.7.0.o Analytis Soft Ins. 2018. Statistical analysis program.

49. WHO. General guidelines for methodologies on research and evaluation of traditional medicine. Geneva. WHO, 2000. p. 29-31. 